\title{
TRADUÇÃO \\ O que significa e com que finalidade se estuda História Universal? ${ }^{1}$
}

\section{TRANSLATION}

What is the meaning of Universal History and the purpose to study it?

\author{
Friedrich Schiller* \\ Tradução: Pedro Spínola Pereira Caldas**
}

Meus honrados senhores, como me deleita e honra a tarefa de, ao vosso lado, percorrer um campo que abriu ao observador inteligente tantos objetos para estudar, ao ativo homem do mundo tantos exemplos notáveis para imitar, ao filósofo tantas explicações importantes e, para cada um, sem exceção, tantas ricas fontes para o mais nobre dos prazeres - o grande e vasto campo da História Geral. Vislumbrar tantos homens jovens e excelentes que me circundam com uma nobre sede de saber e em cujo meio, já floresce algum gênio ativo para a próxima geração, faz de meu dever um prazer, entretanto, me faz sentir, em toda a sua abrangência, também, o seu peso e a sua importância. Quanto maior o valor do presente que lhes devo entregar - e o que de mais valoroso pode o ser humano dar do que a verdade? - tanto mais trago comigo a preocupação de que a riqueza da mesma não diminua em minhas mãos. O quanto mais vivo e puro o vosso espírito, nesta época feliz, receber o seu impacto, e quanto mais rápido os vossos sentimentos juvenis flamejarem, tanto maior é a minha responsabilidade de prevenir que este entusiasmo, que somente a verdade tem o direito de despertar, não se desperdice em fraude e ilusão.

\footnotetext{
${ }^{1}$ Título Original: Was heisst und zu welchem Ende studiert man Universalgeschichte? In: SCHILLER, Friedrich. Werke in Drei Bänden: Zweiter Band. Herbert Göpfert (Org.). München; Wien: Carl Hanser Verlag, 1966, p. 9-22. O texto de Schiller foi apresentado originalmente como uma Antrittsvorlesung (aula magna) na Universidade de Jena, em 26 de maio de 1789.

* Friedrich Schiller (1759-1805) foi um dramaturgo, poeta, filósofo e historiador alemão. Schiller foi um dos grandes homens das letras da Alemanha do século XVIII e, assim como Goethe, Christoph Martin Wieland e Johann Gottfried von Herder, foi um dos principais representantes do Romantismo alemão e do Classicismo de Weimar. Sua peça mais famosa, Guilherme Tell, dramatiza a guerra de libertação da Suíça diante do império austríaco, no início do século XIV, isto é, a luta vitoriosa dos suíços pela liberdade e contra a tirania (N. do E.).

** Doutor em História Social da Cultura pela Pontifícia Universidade Católica do Rio de Janeiro (PUCRio). Professor Associado do Departamento de História da Universidade Federal do Estado do Rio de Janeiro (UNIRIO). Pesquisador do CNPq.
}

Recebido em outubro de 2017 | Aprovado em fevereiro de 2018. 
Fecunda e bem vasta é a área da História; em seu círculo reside todo o mundo moral. Através de todas as circunstâncias vividas pelo ser humano, através de todas as formas alternativas de opinião, através de sua estupidez e de sua sabedoria, de sua piora e de seu aperfeiçoamento, a História o acompanha naquilo que ele tomou e deu, e assim ela deve lhe prestar contas. Dentre todos vós, senhores aqui presentes, não há nenhum para quem a História não tenha nada de importante a dizer. Por mais diversas que sejam vossas futuras trajetórias, em algum lugar elas se unirão na História. Mas um destino todos vós partilhais da mesma forma, precisamente aquele que os trouxe ao mundo educarem-se como seres humanos - e é justamente para os seres humanos que a História fala.

Porém, antes de começar, meus honrados senhores, a determinar com mais exatidão suas expectativas perante este objeto de vossos esforços e a propiciar as ligações de suas finalidades específicas com vossos diversos estudos, não será supérfluo entrar em um acordo com os senhores sobre a própria finalidade de vossos estudos. Um esclarecimento provisório dessa questão, que me parecesse ao menos adequado e digno o suficiente para abrir a nossa futura relação acadêmica, me coloca na posição de chamar vossa atenção para o lado mais digno da história mundial.

É diferente o plano de estudos que se prescreve o estudioso ganha-pão [Brotgelehrter ${ }^{2}$, ao menos distinto daquele estabelecido por uma cabeça filosófica. $\mathrm{O}$ primeiro se esforçará única e exclusivamente em preencher as condições as quais o tornarão capaz de assumir um emprego de cujas vantagens fará bom proveito, e só ativará as forças de seu intelecto para melhorar sua situação material e satisfazer um mesquinho desejo de fama. Para alguém assim, já desde o princípio de sua trajetória acadêmica, não há nada de mais importante do que distinguir cuidadosamente entre as ciências chamadas de ganha-pão [Brotstudien] de todas aquelas que satisfazem o espírito apenas como espírito. Ele acredita que todo o tempo dedicado a essas apenas servirá para afastá-lo de sua futura profissão e, por essa perda de tempo, ele jamais se perdoará. Todo o seu esforço será organizado a partir das exigências que lhe serão feitas pelo futuro senhor de seu destino e terá acreditado ter feito de tudo ao seu alcance para não temer essa instância. Tendo atravessado o seu percurso e atingido seus objetivos, ele deixa em um canto as ciências que o conduziram até o fim - afinal, por que ainda se

\footnotetext{
${ }^{2}$ Trata-se de uma expressão tipicamente alemã: o estudo para ganhar o pão, interessada pragmaticamente em assegurar futuramente um emprego que não lhe faça passar necessidades e adquirir algum respeito social. Tal pragmatismo implica também um desinteresse pela reflexão teórica e pelos fundamentos conceituais e universais de todo o conhecimento (N. do T).
} 
ocupar delas? Sua grande preocupação, agora, é tornar visível e até mesmo proteger esse grande tesouro acumulado na memória, para que seu valor não se perca. Toda ampliação de seus estudos ganha-pão o inquieta, porque lhe dá mais trabalho e porque torna inútil o que aprendera antes; toda importante renovação o aterroriza, pois rompe antigas fórmulas escolares das quais ele se apropriou com tanta dedicação e põe em risco a perda de todo o trabalho da sua vida pregressa. Quem gritou mais contra os reformadores do que a horda dos estudiosos ganha-pão? Quem freia o progresso de revoluções úteis no conhecimento do que eles? Toda luz que seja acesa por meio de um gênio feliz, não importa em que ciência, torna sua indigência visível. Eles lutam exasperadamente, com malícia, com desespero, pois, ao lutar em defesa de todo um sistema de ensino, lutam por sua própria existência. Por essa razão, não há inimigo mais irreconciliável, não há funcionário mais invejoso, ninguém mais disposto a denunciar heresias do que o estudioso ganha-pão. Quanto menos os seus conhecimentos, por si mesmos, o recompensam tanto maior a retribuição que exige de fora; para o ganho do trabalhador manual e para o ganho dos intelectos só há uma medida: o esforço. Por isso, ninguém ouve tantas reclamações de ingratidão como se ouve de um estudante pragmático; não é pelo tesouro de pensamentos que ele recebe seu pagamento; seu pagamento provém do reconhecimento externo, dos lugares de honra, das provisões. Caso lhes falte, quem poderia ser mais infeliz do que o estudante pragmático? Ele terá vivido, trabalhado e se preocupado em vão; ele terá buscado a verdade em vão se a verdade não se transformar em ouro, em elogios no jornal, em apreço de príncipes.

É digno de pena o homem que, de posse das mais nobres ferramentas - a arte e a ciência -, não almeja nem deseja nada além do que o assalariado, de posse das piores ferramentas! Que, enquanto anda pelo reino da liberdade, carrega consigo uma alma de escravo! Ainda mais digno de pena é o jovem de gênio, cujo percurso que seria naturalmente belo, é desvirtuado por doutrinas e exemplos danosos para esse triste caminho, e acaba persuadido a assimilar detalhes direcionados para sua futura profissão. Logo sua ciência profissional, transformada em um mosaico, lhe causará desgosto; nele despertarão desejos que esses detalhes não poderão satisfazer e seu gênio se voltará contra o seu destino. Tudo que ele faz parece ser fragmentado, ele não vê finalidade em sua ação e ele não pode suportar esta ausência de sentido. O que há de cansativo e trivial em sua ocupação profissional o arrasta para o chão e a isso ele não consegue resistir com uma coragem alegre, algo que só acompanha o claro conhecimento e a perfeição vislumbrada. Ele se sente isolado, separado do contexto das coisas, pois ele abdicou de 
ligar sua atividade à grande totalidade do mundo. De nada mais serve ao jurista sua ciência do Direito assim que o brilho de uma cultura melhor o ilumine com sua translucidez; ao invés de insistir, ele, deveria, de imediato, tentar se esforçar em ser um novo criador dela e superar as lacunas descobertas a partir de sua própria plenitude interior. O médico se divorcia de sua profissão, assim que erros importantes lhe mostram o quão seu sistema não é confiável; o teólogo perde a consideração por seus pares assim que vacila sua fé na infalibilidade de seu corpo doutrinal.

E como se comporta de maneira diferente a mente filosófica! - Com o mesmo cuidado que o estudioso ganha-pão distingue sua ciência das demais, o filósofo se esmera em ampliar sua área e a reestabelecer sua ligação com as outras ciências - eu disse estabelecer, pois somente a inteligência abstrata demarcou aquelas fronteiras, separou aquelas ciências das outras. Onde o estudioso ganha-pão separa, a inteligência filosófica une. Antigamente, o filósofo se convencera de que, no âmbito da inteligência, assim como no mundo dos sentidos, tudo se interpenetrava, e seu dedicado impulso em buscar a concordância entre tudo jamais pode se satisfazer com fragmentos. Todos os seus esforços se direcionam para o aperfeiçoamento de seu saber; toda sua nobre impaciência não pode ser acalmada até que todos os seus conceitos estejam ordenados em um todo harmônico, até que ele se encontre no ponto nodal de sua arte e de sua ciência e, a partir dele, possa, então, contemplar seu campo de estudos com um olhar satisfeito. Novas descobertas no círculo de sua atividade, que derrotam o estudioso ganha-pão, atiçam seu espírito filosófico. Talvez essas novas descobertas preencham uma lacuna que ainda deixava deformada a totalidade de seus conceitos, ou ainda coloquem a última pedra que faltava em seu edifício de ideias que, justamente, o torna perfeito. Mas caso as descobertas venham a demoli-lo, caso um novo sistema de pensamentos, um novo fenômeno da natureza, uma nova lei no mundo físico destrua todo o seu edifício: - então, ele terá amado a verdade mais do que o seu sistema e, com prazer, trocará a antiga forma defeituosa por uma nova e mais bela. Sim, quando nenhum entrave externo abala seu edifício de ideias, então, ele é movido por um eterno impulso de aperfeiçoamento, ele mesmo é o primeiro a declará-lo insatisfatório e a reconstruí-lo de maneira aprimorada. Através de formas de pensamento cada vez mais novas e mais belas, o espírito filosófico progride rumo a uma excelência cada vez mais elevada, enquanto o estudioso ganha-pão se protege, em uma eterna monotonia intelectual, na obviedade infrutífera de seus conceitos escolares. 
Não há juiz mais justo dos méritos alheios do que a mente filosófica. Sagaz e inventiva o suficiente para se apropriar de todo tipo de atividade, ela é também justa o suficiente para honrar mesmo a criação das coisas mais ínfimas. Para a mente filosófica, trabalham todas as outras mentes - e todas as outras mentes trabalham contra o estudioso ganha-pão. A mente filosófica sabe assimilar tudo aquilo que a cerca, todos os pensamentos que a circundam; entre as mentes pensantes vige uma comunidade interna de todos os bens do pensamento; a conquista de um no terreno da verdade se torna uma conquista de todos. O estudioso ganha-pão erige uma cerca contra todos os seus vizinhos, a quem ele invejosamente nega luz e sol, e observa atentamente os muros deteriorados, que ele debilmente protege contra a razão prevalente. Para tudo que empreende, o estudioso ganha-pão precisa pegar emprestado estímulo e encorajamento externos: a mente filosófica encontra estímulo e recompensa em seu objeto, em seu próprio esforço. E como ele se ocupa com mais entusiasmo de seu trabalho, como é mais vivo o seu zelo e como é mais duradoura a sua coragem e sua atividade, posto que, para a mente filosófica, o trabalho se rejuvenesce pelo próprio trabalho! Mesmo o pequeno se torna grande em suas mãos criativas, posto que ele tem sempre em vista o grande a quem serve, ao passo que o estudioso ganha-pão vê no grande apenas o pequeno. Não é o que se pratica e se faz que distingue a mente filosófica. Onde quer que ela esteja e aja, sempre está no centro do todo; e, por mais distante que esteja de seus irmãos o objeto de seu trabalho, a mente filosófica lhes é afim e próxima através de um entendimento harmônico e dinâmico, no qual todas as mentes esclarecidas se encontram.

Devo prosseguir com esta descrição ou posso esperar que já esteja decidido em cada um dos senhores qual dos dois quadros, que lhes apresentei, devem escolher como modelo? Dessa decisão que os senhores devem tomar entre ambos, depende da minha recomendação ou não do estudo da História universal. Só me diz respeito o segundo modelo, pois na opção de se aproveitar do primeiro, a própria ciência fica muito distante de sua finalidade mais elevada e será vendida a um preço alto com retornos muito baixos.

Uma vez de acordo com os senhores acerca do ponto de vista a partir do qual podemos determinar o valor de uma ciência, posso me debruçar sobre o conceito de História universal, o objeto da preleção de hoje.

As descobertas feitas em mares distantes e costas remotas por nossos viajantes europeus nos fornecem um drama tão instrutivo quanto envolvente. Elas nos mostram 
populações dos mais variados níveis de cultura que nos cercam da mesma forma que crianças de diferentes idades em volta de um adulto? À volta de um adulto o lembram, por seu exemplo, como ele costumava ser e de onde ele proveio. Uma mão sábia parece nos ter preservado estes povos primitivos até o momento em que nós, em nossa própria cultura, já teríamos feito progressos suficientes para fazermos uma aplicação útil para nós mesmos e fazer refletir o início perdido de nossa espécie. Mas como é vergonhoso e triste a imagem que esses povos nos dão de nossa infância! E não é nem mais no primeiro degrau que nós os olhamos. O ser humano começou de maneira ainda mais desprezível. Afinal, já podemos encontrar nesses povos corpos políticos, mas somente através um esforço extraordinário o ser humano evoluiu para uma sociedade política.

O que nos contam dessas selvagens os relatos de viajantes? Alguns os encontraram sem qualquer contato com as artes mais elementares, os encontraram sem o conhecimento do ferro, do arado, e alguns até sem o domínio do fogo. Alguns ainda vagueiam com animais selvagens em busca de comida e moradia, e, em muitos outros, a linguagem ainda mal passara do estágio de sons animalescos para os de signos compreensíveis. Ora não se encontrava o simples laço do casamento, ora qualquer conhecimento da propriedade; ora a alma tíbia não conseguia registrar uma experiência repetida todos os dias; observa-se o quão descuidadamente o selvagem se desfazia do leito onde acabara de dormir, sem lhe ocorrer que ele tornaria a adormecer. Em contrapartida, a guerra estava em toda a parte e, não raro, o prêmio do vencedor era a carne do inimigo derrotado. Em outros, mais habituados com condições de vida diversas, tendo já atingido outro nível cultural, exibem um quadro pavoroso de escravidão e despotismo. Já se viu um déspota da África trocar seus súditos por um gole de aguardente: - no mesmo caso, seus súditos foram mortos no túmulo do déspota para que o servissem na vida póstuma. Ora a piedade simplória se prostra diante de um fetiche ridículo, ora perante um monstro aterrorizante; o ser humano se pinta em seus deuses. Se aqui o ser humano se curva profundamente sob a escravidão, a estupidez e a superstição, acolá, em outro extremo, o ser humano é miserável em sua liberdade desprovida de leis. Sempre preparado para atacar e defender, sobressaltado por cada ruído, o ouvido espantado do selvagem se estende pelo deserto. Ele chama de inimigo tudo que lhe é novo; coitado do estrangeiro que é levado pela tempestade até suas costas marítimas! Não será aquecido por nenhuma fogueira acolhedora, não será celebrado por nenhuma regra de hospitalidade. Mas mesmo quando o ser humano passa de uma solidão hostil para a sociabilidade, da carência para o bem-estar, do temor para a alegria 
- o quão bizarro e monstruoso ele se apresenta aos nossos olhos! Seu gosto tosco busca alegria na torpeza, beleza na distorção, glória na desmedida; suas virtudes nos despertam repulsa e aquilo que eles chamam de felicidade pode somente nos suscitar asco ou compaixão.

Assim éramos nós. César e Tácito não nos achavam muito melhores mil e oitocentos anos atrás.

O que somos agora? - Permitam-me que me detenha um instante na época em que vivemos, que me atenha à forma presente do mundo em que habitamos.

O esforço humano cultivou essa forma, dominando o solo resistente com sua persistência e sagacidade. Ora ele consegue aterrar o mar, ora ele irriga a terra árida. $\mathrm{O}$ homem integrou regiões e estações do ano, tornando, debaixo de seu céu, mais resistentes as frágeis plantas do Oriente. Assim como ele levou a Europa aos mares do sul e às Índias Ocidentais, permitiu que a Ásia renascesse na Europa. Um céu mais sereno sorri sobre as florestas germânicas, cortadas pela forte mão humana e agora abertas aos raios do sol, e nas ondas do Reno se espelham as vinhas da Ásia. Às suas margens se ergueram cidades populosas que aglomeram prazer e trabalho em uma vida intensa. Aí, encontramos o homem seguro em sua conquista pacífica da propriedade, o mesmo homem a quem, anteriormente, um único vizinho poderia tirar o sono. A igualdade perdida quando ele entra na sociedade é recuperada através de leis sábias. Da opressão cega do acaso e da necessidade foge mediante o domínio muito mais suave dos contratos, tal como abandonou a liberdade dos animais para preservar a liberdade muito mais nobre dos seres humanos. Com boa vontade, separaram suas ocupações, dividiram suas atividades. Nenhuma imperiosa carência material o leva mais a pegar no arado, nenhum, assim como nenhum inimigo o obriga a empunhar a espada no campo de batalha para proteger sua pátria e seu lar. Com seus braços, o camponês, agora, enche seu celeiro e, com as suas armas, o guerreiro protege sua região. A lei observa sua propriedade - e a ele cabe o direito inestimável de escolher seus próprios deveres.

Quantas criações artísticas, quantas maravilhas do esforço, quanta luz em todos os campos do saber desde que o homem deixou de se consumir inutilmente na triste defesa de suas próprias forças, desde que, a partir de seu próprio arbítrio, pôde lidar com suas próprias necessidades que jamais serão totalmente contornáveis; desde que conquistou o precioso direito de dispor de sua própria capacidade e de seguir o chamado de seu próprio gênio! Quantas atividades florescem em todos os cantos desde que os mais variados desejos deram novas asas ao espírito criativo, abrindo novos espaços para 
o esforço! - Quebram-se as barreiras que separavam, em um egoísmo hostil, as nações e os Estados. Todas as cabeças pensantes estão agora universalmente ligadas e toda a luz de seu século pode agora iluminar o espírito de um novo Galileu e de um novo Erasmo.

Desde que as leis se rebaixaram às fraquezas do homem, ele foi de encontro às leis. Com elas, o homem se tornou mais gentil da mesma forma que ele se tornou mais selvagem com elas; suas punições bárbaras geraram, paulatinamente, crimes bárbaros no passado. Deu-se um grande passo para o enobrecimento quando as leis se tornaram virtuosas, mesmo que os homens ainda não o fossem. Uma vez deixados de lado os deveres impostos ao homem, esse é tomado pela moralidade. O homem não é mais aterrorizado pela lei e constrangido pela consciência, mas é sustentado pelas leis da decência e da honra.

É verdade que, também em nossa época, ainda permanecem alguns resquícios bárbaros do passado, filhos do acaso e da violência, que a era da razão não deve eternizar. Mas que finalidade o entendimento do homem deu também a esse legado bárbaro dos séculos antigos e medievais! E como o entendimento tornou inofensivo e até mesmo útil aquilo que ele não ousou ainda destruir! Sobre os fundamentos toscos da anarquia feudal, a Alemanha criou o sistema de sua liberdade política e religiosa. A silhueta do Imperador Romano, que se manteve intacta neste lado dos Apeninos, faz muito mais bem ao mundo do que sua terrível imagem original nos tempos da Roma antiga - pois ela mantém unida, através da união, um útil sistema estatal, ao passo que a segunda reprimia as forças mais ativas da humanidade em uma escravidão uniforme. Mesmo a nossa religião - tão desfigurada por mãos traidoras, por meio das quais ela chegou até nós: quem pode deixar de reconhecer nela a influência enobrecedora sobre a melhor filosofia? Nosso Leibiniz e Locke são tão devedores do Dogma e da Moral cristãs quanto os pincéis de um Rafael e de um Correggio são da História sagrada.

Por fim, nossos Estados - com que ardência, com que arte eles se integraram uns com os outros! Irmanados de maneira muito mais duradoura pela imposição benevolente da miséria do que anteriormente pelos acordos mais festejados! Uma guerra permanentemente encarniçada garante a paz e o amor-próprio de um Estado o transforma em vigia do bem-estar do outro. A sociedade europeia de Estados parece ter se transformado em uma grande família. Os parentes podem até polemizar uns com os outros, mas não dilacerá-los.

Que quadros mais opostos! Quem poderia supor o sofisticado sistema? Estado? O europeu do século XVIII é apenas um irmão mais evoluído do novo canadense ou do 
antigo celta? Todas essas habilidades, todos esses impulsos artísticos, todas essas experiências, todas essas criações da razão foram plantadas e desenvolvidas no homem em um espaço de poucos séculos; todas essas maravilhas da arte, essa obra gigantesca do esforço, foram evocadas de dentro do homem. O que as traz à vida, o que as atiçou? Por quais condições atravessou o homem até que saísse daquele extremo para este outro extremo, passando de um hostil habitante das cavernas para um pensador intelectualmente brilhante, para um cosmopolita culto? A História universal dá uma resposta a essa pergunta.

O mesmo povo, no mesmo território, nos mostra incomensuravelmente diferente se o olharmos em diversos espaços de tempo! Não menos conspícua é a diferença entre gerações contemporâneas, mas que habitam diferentes países. Que diversidade de hábitos, leis, costumes! Que mudança brusca das trevas para as luzes, da anarquia para a ordem, da felicidade para a miséria, mesmo quando observamos o homem no pequeno pedaço do globo chamado Europa! Livre no Tâmisa, e dessa liberdade é seu próprio credor; invencível nos Alpes, imbatível entre seus rios artificiais e seus pântanos; fraco às margens do Vístula e miserável por causa de sua discórdia; além dos Pirineus, igualmente fraco e miserável por causa de sua calmaria; carente e infeliz às margens do paraíso inutilizado do Ebro. Ora, dois povos distantes entre si, com um oceano a separálos, transformados em vizinhos pela necessidade, esforço artístico e laços políticos; mas, afinal, dois vizinhos de um mesmo rio, irremediavelmente separados por uma liturgia diferente. O que conseguiu o poder da Espanha, atravessando o Oceano Atlântico e penetrando o coração da América, mas não obteve no Tejo e no Guadiana? O que fez com que tantos tronos na Itália e na Alemanha fossem preservados e, na França, desaparecessem todos, menos um? - A História universal soluciona esta questão.

Até mesmo o fato de nos encontrarmos juntos, neste instante, com este grau de cultura nacional, com esta língua, esta moral, estes privilégios civis, com este padrão de liberdade de consciência, é talvez o resultado de todos os acontecimentos mundiais pretéritos: toda a História universal nos seria necessária ao menos para nos esclarecer esse momento. Para que nos encontremos como cristãos, essa religião precisou, preparada por inúmeras revoluções, surgir do judaísmo, precisou encontrar o Estado romano da forma tal como o encontrou, para se espalhar pelo mundo como um veloz vento triunfante para, finalmente, derrubar o trono de César. Nossos toscos antepassados nas florestas da Turíngia precisaram ser derrotados pelo poder superior 
dos francos para aceitar sua crença. Através de suas riquezas crescentes, da ignorância dos povos e da fraqueza de seus governantes, o clero precisou ser tentado e beneficiado a abusar de sua reputação e transformar seu sereno poder sobre as consciências em uma espada secular. Se podemos estar aqui reunidos como protestantes, é porque a hierarquia precisou derramar, com um Gregório e com um Inocêncio, todas as suas atrocidades sobre o gênero humano de modo que a deterioração disseminada dos costumes e o escândalo gritante do despotismo espiritual pudessem levar um inabalável monge agostiniano a dar o sinal para o levante e arrancar da hierarquia católica a metade da Europa. Para que isso fosse possível, foi preciso que as armas de nossos príncipes extraíssem de Carlos V uma paz religiosa; um Gustavo Adolfo precisou retaliar o rompimento dessa paz para estabelecer uma nova paz que duraria séculos. Na Itália e na Alemanha, cidades inteiras precisaram se erguer e abrir as suas portas ao trabalho, romper as correntes da servidão, arrancar o cetro das mãos de tiranos ignorantes, e, por meio da Liga Hanseática, chamarem a atenção para si, caso quisessem que o comércio e os negócios florescessem, que o supérfluo evocasse nas artes a alegria, caso o Estado quisesse honrar o camponês útil, e, nos homens de boa-fé das camadas médias, criadoras de toda a nossa cultura, preparar uma felicidade duradoura para a humanidade. Por séculos, o Imperador da Alemanha precisou lutar com os papas, com seus vassalos e com seus vizinhos invejosos; a Europa precisou descarregar seus perigosos excessos nos túmulos da Ásia, a lamentável nobreza feudal viu esvair-se seu espírito de revolta sob leis draconianas, campanhas católicas e cruzadas: até que o caos desconcertante cessasse e as potências estatais beligerantes chegassem a um equilíbrio, cujo prêmio é a tranquilidade de que desfrutamos. Para que nosso espírito tivesse que sair da ignorância, no qual se manteve atado por necessidades materiais e espirituais, a semente da erudição, tão longamente abafada, teve que florescer em meio aos mais encarniçados perseguidores, e teria que retribuir a um Al Mamun das ciências o que um Omar lhe roubara. A intolerável miséria da barbárie fez com que nossos antepassados passassem a fazer julgamentos humanos, ao invés de sangrentos julgamentos divinos, pragas devastadoras levaram uma medicina desvirtuada a voltar ao estudo da natureza, a indolência dos monges precisou, à distância, preparar um substituto para o mal criado por suas atividades, e o trabalho profano nos monastérios teve que preservar as ruínas da época de Augusto até os tempos da impressão dos livros. O oprimido espírito dos bárbaros nórdicos precisou se erguer a partir dos exemplos dos gregos e dos romanos e a erudição estabeleceu um laço com as musas e as graças, caso tivesse que encontrar um 
caminho para os corações e fizesse por merecer o nome de uma escultora dos seres humanos. Mas teria a Grécia um Tucídides, um Platão, um Aristóteles, teria Roma um Horácio, um Cícero, um Virgílio, um Lívio, se ambos os Estados não tivessem alcançado uma estabilidade política de tão alto nível? Em uma palavra - se não tivessem toda a sua história atrás de si? Quantas invenções, descobertas, revoluções estatais e religiosas precisaram se encontrar para dar, às sementes tão delicadas da ciência e da arte, o crescimento e a difusão que teriam?! Quantas guerras precisaram ser travadas, quantas alianças precisaram ser feitas, desfeitas, para que a Europa pudesse obter uma estrutura pacífica? Só uma paz assim poderia permitir aos Estados, como a seus cidadãos, chamar a atenção para si e reunir forças para atingir um objetivo comum.

Mesmos nas atividades cotidianas da vida civil, não podemos deixar de nos sentir em dívida com os séculos passados; os mais diversos períodos da história da humanidade desaguam na nossa cultura, assim como as mais diversas partes do globo em nosso luxo. As roupas que vestimos, os temperos em nossos pratos e o preço pelo qual os compramos, muitos de nossos medicamentos mais poderosos e até mesmo muitos instrumentos de nossa degradação - não pressuporiam a existência de um Colombo que descobriu a América, de um Vasco da Gama que descobriu o caminho para as Índias?

Desfia-se, portanto, uma longa sequência de eventos desde o momento presente até o começo do gênero humano, entremeados por uma relação de causa e efeito. Somente a inteligência infinita pode vê-los em sua totalidade e completude; ao homem são impostos limites mais estreitos.

I. Inúmeros desses eventos não foram observados nem testemunhados por seres humanos ou não foram preservados sob qualquer sinal. Pertencem a esses eventos todos aqueles que precederam o próprio homem ou a invenção da escrita. A fonte de toda tradição e o órgão da tradição é a linguagem. Toda a época anterior à linguagem, por mais rica que seja para o mundo, está perdida para a história mundial ${ }^{3}$.

II. Depois que a linguagem foi inventada e que, mediante ela, passasse a ser possível expressar e comunicar as coisas que aconteceram, essa comunicação se deu, no início, sob a forma incerta e mutável das sagas. De boca em boca, arraigou-se um evento por meio de uma longa sequência de gerações e, como tal sequência se deu por

\footnotetext{
${ }^{3}$ Para manter a comparação de Welt (mundo no sentido mais natural e geográfico) com Weltgeschichte optou-se, excepcionalmente, neste caso, por traduzir a última por História mundial, ao invés de História universal, como em outras ocasiões no texto (N. do T.).
} 
meios mutáveis e transformadores, o evento foi modificado junto com as próprias sagas. A tradição viva ou a saga oral é uma fonte pouco confiável para a História de modo que todos os eventos anteriores à invenção da escrita estão definitivamente perdidos.

III. A própria escrita também não é perene. O tempo e o acaso se encarregaram de destruir incontáveis monumentos da Antiguidade e somente algumas ruínas desse mundo pregresso foram salvas pela era do livro impresso. A maior parte dele, com todas as suas informações, está perdida para a História universal.

IV. A maior parte dentre os poucos poupados pelo tempo foi deformada e tornada irreconhecível pela paixão, pela estupidez e até mesmo pela genialidade de seus narradores. Surge logo a desconfiança perante os antigos monumentos históricos, algo que não nos deixa mesmo quando observamos a crônica da nossa atualidade. Quando acontece um fato hoje em dia, entre homens com os quais vivemos, sempre ouvimos as testemunhas e precisamos nos esforçar para decifrar a verdade a partir de suas afirmações contraditórias. Quanta coragem devemos ter para estudar nações e tempos que distam de nós mais pela diferença dos hábitos do que pelos séculos? - A pequena soma de fatos que resta após todos esses descontos é o material da História em seu sentido mais amplo. E o que e quanto desse material pertence à História universal? De todo o conjunto desses fatos, a História universal destaca aqueles que tenham influenciado de maneira essencial, coerente e facilmente discernível a forma atual do mundo e a situação da geração de hoje. A História mundial parte de um princípio que se contrapõe ao do início do mundo. A verdadeira sequência dos fatos perfaz um curso descendente da origem das coisas à sua ordem mais recente. $\mathrm{O}$ pensamento do historiador parte do ano e século correntes rumo aos anteriores e nota, entre os fatos fornecidos pelo momento anterior, aqueles que contêm uma explicação sobre o próximo - se ele percorrer esse caminho passo a passo até o início, não dos tempos, pois não há nenhum guia que o levará até ele, mas dos documentos, então, caberá a ele retornar pelo caminho percorrido e fazer o caminho ascendente, sem obstáculos e tranquilamente, a partir do fio condutor desses fatos significativos. Essa é a História mundial que nós temos e que lhes será apresentada.

Por ser a História mundial dependente da riqueza e da escassez de fontes, surgem, portanto, lacunas na História mundial, como se houvesse trechos vazios na transmissão. Por mais que as mudanças mundiais ocorram articuladamente de maneira uniforme, necessária e lógica, na História, elas são estruturadas de forma contingencial e sem conexão. Por esta razão, há um descompasso visível entre o mundo e o processo 
da História mundial. Enquanto aquelas podem ser comparadas com uma correnteza contínua, a História universal é apenas uma luz que incide aqui e acolá sobre as ondas. Posto que pode facilmente acontecer que a relação entre contexto de um distante evento mundial com a circunstância atual faça sentido antes da ligação entre os dias de hoje e os eventos imediatamente antecessores ou exatamente contemporâneos, então, é inevitável que os fatos, mais intimamente ligados à época recente, apareçam, em seu contexto, não raro, como fatos isolados. Um fato desse tipo seria, por exemplo, a origem da cristandade e especialmente da doutrina moral cristã. A religião cristã tem uma parcela de importância tão grande na atual forma do mundo que o seu surgimento é o fato mais importante para a História mundial, mas nem no tempo em que ela apareceu, nem no povo no qual ela nasceu se encontra (por falta de fontes) uma explicação satisfatória de seu surgimento.

Então, nossa História mundial não seria outra coisa além de um agregado de fragmentos e jamais mereceria o nome de ciência. É aí que lhe auxilia a inteligência filosófica e, à medida que essa articula mediante conexões artificiais, ela eleva esse agregado à condição de sistema, a um todo racional e coerente. Sua autoridade reside na uniformidade e na inalterável unidade das leis da natureza e da alma humana, cuja unidade é a causa de que eventos da mais longínqua antiguidade, sob a influência das mesmas condicionantes exteriores, retornem nos processos temporais dos dias de hoje; e de que também, a partir dos eventos mais recentes, que estão em nosso campo de visão, uma nova conclusão pode ser feita e uma nova luz pode ser incidida, retrospectivamente, sobre tempos imemoriais. O método de se estabelecer analogias é, na história, como em qualquer canto, um auxílio poderoso: mas ele precisa ser justificado por um motivo relevante e também ser manuseado com muito cuidado e sensatez.

O espírito filosófico não pode se demorar muito ao lidar com o material da História universal, do contrário, um novo impulso lhe será ativado, a saber, o que busca concordância em todo - algo que o estimula irresistivelmente, fazendo com que assimile tudo dentro de sua natureza racional, elevando cada fenômeno com que depara a um efeito maior, a pensamentos. O quanto mais frequentemente ele renovar com resultados meritórios a articulação entre passado e presente, tanto maior será sua inclinação de articular como meio e fim o que vira como causa e efeito. Um fenômeno após o outro, tudo começa a se desprender do acaso cego e da liberdade anárquica, e a se configurar como um todo harmonioso (que somente existe em sua imaginação), a se articular como 
uma teia bem tecida. Logo lhe será difícil se deixar convencer que essa sequência de eventos, que em sua imaginação adquire regularidade e finalidade, é negada pela realidade; ser-lhe-á penoso atribuir novamente ao domínio cego da necessidade o que começara a ganhar, sob a luz emprestada pela inteligência, uma forma tão brilhante. Ele retira essa harmonia de si mesmo e a transplanta para a ordem das coisas, isto é, emprega a sua intencionalidade racional para o curso do mundo e um princípio teleológico para a História universal. Com este princípio, o espírito filosófico a atravessa e dá por comprovável todo fenômeno que lhe é oferecido por esse grande palco. Ele vê esse princípio confirmado por milhares de fatos determinados e igualmente contraditos por tantos outros fatos; mas na medida em que, na sequência das alterações que ocorrem no mundo ainda faltam muitos elos, na medida em que o destino ainda reserva para si o sentido de muitos fatos, ele declara a questão indefinida, e vence aquela opinião que oferece maior satisfação à inteligência e maior felicidade aos corações.

Não é necessário lembrar que uma História mundial, de acordo com os planos acima mostrados, somente pode ser encontrada em tempos mais recentes. Uma aplicação precipitada deste grande padrão pode facilmente tentar o historiador a violentar os fatos e afastar mais e mais dessa época feliz a possibilidade de se fazer uma História mundial, justamente por querer fazê-la rapidamente. Mas nunca é cedo demais chamar a atenção para este luminoso e, todavia, ainda ignorado lado da História mundial, por meio do qual se ata ao objeto o mais elevado de todos os esforços humanos. Mesmo um olhar breve sobre esses esforços, mesmo quando a meta é apenas uma possibilidade, deve dar um estímulo revigorante e um doce prazer ao trabalho do pesquisador. Para ele, será importante, mesmo a ocupação humana mais humilde, caso saiba o caminho que está percorrendo ou quando sabe que legará a seu sucessor a solução do problema da ordem universal e a tarefa de encontrar o espírito superior em sua máxima elevação.

Trabalhado desta maneira, meus digníssimos senhores, o estudo da História universal vos propiciará uma ocupação tão atraente quanto útil. Ela trará luz para as vossas inteligências e estímulo benevolente em vossos corações. Ela desacostumará vossos espíritos das visões medíocres e mesquinhas, e à medida que o grande quadro dos tempos e dos povos se expor frente aos vossos olhos, essas visões aperfeiçoarão as decisões precipitadas tomadas no momento e o juízo egoísta limitado. À medida que a História mundial acostumar os homens a se integrarem com o passado e a anteciparem 
os resultados do futuro distante: - ela tenderá a apagar as fronteiras entre o nascimento e a morte que restringem de maneira tão estreita e opressora a vida do homem e ampliará, como se fosse uma ilusão de ótica, sua breve existência por um espaço infinito e, imperceptivelmente, o indivíduo será alçado à sua espécie.

O homem muda e sai de cena. Suas opiniões são fugazes e mudam com ele: a História, porém, permanece incessante sobre o palco, uma cidadã eterna de todas as nações e de todos os tempos. Assim como o Zeus homérico, ela olha de cima com o mesmo olhar impassível os trabalhos sangrentos das guerras e dos povos pacíficos, serenamente, ela observa os dramas confusos: pois seu olhar abrangente já desvenda o que está à distância, quando a liberdade desregrada é conduzida para o lado da necessidade. O que ela não revela para a consciência punitiva de um Gregório ou de um Cromwell, ela se apressa a mostrar para a humanidade: “o homem egoísta pode até perseguir objetivos mesquinhos, mas inconscientemente ajuda a atingir objetivos nobres".

Nenhum falso brilhante cegará a História, nenhum preconceito de um tempo a seduzirá, pois ela vivencia o destino final de todas as coisas. Tudo que termina tem para ela a mesma breve duração: ela segura com frescor a coroa de louros e derruba os obeliscos erigidos pela vaidade; à medida que destrincha o fino mecanismo através do qual a mão serena da natureza desde o início do mundo já havia desenvolvido, de acordo com um plano, e à medida que indica, com precisão, o que cada época ganhou com esse plano de natureza, então, ela instaura novamente a verdadeira medida para a felicidade e para o mérito, cuja loucura predominante em séculos anteriores falsificara. Ela nos cura da admiração exagerada da Antiguidade e da nostalgia infantil por tempos pretéritos; e à medida que ela nos chama a atenção para as nossas próprias características, não nos faz desejar retroativamente os louvados tempos dourados de Alexandre e Augusto.

Todos os séculos anteriores - sem sabê-lo ou involuntariamente - contribuíram para que chegássemos ao nosso século humano. São finalmente nossos todos os tesouros criados pelo esforço e pelo gênio, pela razão e pela experiência, trazidos pelos séculos antigos. Somente com a história os senhores aprenderão a atribuir valor a bens que, pela força do hábito e por estarem simplesmente à disposição, não recebem a nossa gratidão: bens estimados e caros, nos quais está grudado o sangue dos melhores e dos mais nobres, que precisaram ser conquistados por meio do trabalho pesado de gerações! E quem entre os senhores, cujo distinto espírito é serenado por um coração sensível, 
poderia estar à altura deste nobre dever sem que despertasse um desejo sutil de pagar uma dívida com a geração seguinte, que essa não poderia suportar? Também a partir de nossos meios, precisa brilhar em nós um desejo de deixar uma contribuição para o rico legado de verdade, moralidade e liberdade herdados de épocas anteriores e que devemos devolver ainda mais rico para o mundo vindouro, e, a partir dessa eterna cadeia em que estão entrelaçados todos os gêneros humanos, legitimar nossa existência transitória. $\mathrm{O}$ quão diferentes são também os destinos que os senhores aguardam na sociedade civil com alguma coisa certamente todos os senhores podem colaborar! Cada conquista é um caminho que se abre para a eternidade, digo: para a verdadeira eternidade em que a ação vive e segue adiante, ainda que o nome de seu autor já tenha ficado para trás. 